\title{
On the Fringes and Vague: Elementary Social Studies from Multiple Perspectives
}

\author{
Derek L. Anderson, Ed.D. \\ School of Education, Northern Michigan University \\ Marquette, Michigan, 49855, United States
}

Tel: 1-906-227-1873_E mail: dereande@nmu.edu

Received: October 9

Accepted: October 14

Published: December 1, 2011

doi:10.5296/jse.v1i1.1010

URL: http://dx.doi.org/10.5296/jse.v1i1.1010

\begin{abstract}
This paper compares one state's Grade Level Content Expectations (GLCEs) for elementary social studies with teacher candidates' definitions of social studies and social studies textbooks. In order examine the extent to which each of the four primary subcategories of social studies (history, geography, civics, and economics) are prioritized, four sources of data were used: Michigan's GLCEs, 190 teacher candidates' definitions, elementary social studies textbooks, and social studies methods textbooks. Using a fully-mixed, concurrent, equal status mixed methods design (Leech \& Onwuegbuzie, 2009), each of the four data sources revealed dominance toward history within the broader social studies umbrella. Despite Michigan's mandate that history, geography, civics, and economics receive nearly equal attention in elementary social studies classrooms, economics and civics are underrepresented. With increased attention on standardized test scores and teachers' salaries tied to those scores, it is imperative that elementary social studies teachers supplement resources in economics and civics.
\end{abstract}

Keywords: Social studies, Teacher education, Curriculum standards 


\section{Objectives/Purpose}

Nearly all definitions of social studies include something about preparing students to be responsible citizens. Thus, it is ironic during this era of regime change, countries on the verge of bankruptcy, and pervasive social media that the time devoted to teaching social studies in the elementary grades is minimal and shrinking (e.g., Bolick, Adams, \& Willox, 2010; Fitchett \& Heafner, 2010; Leming, James, Ellington, \& Schug, 2007; Lintner, 2006; McGuire, 2007). The marginalization of social studies is nothing new. Though, evidence suggests it is worsening.

More than any other subject, social studies suffers from limited teachable time, yet ironically, social studies content grows most rapidly. Compounding this problem is the lack of clarity regarding what social studies is. Before educators can improve the frequency and quality of social studies instruction in our elementary schools, it is essential to understand what social studies is. However, as Zevin (2007) asserted, "Educators have never agreed on common definition of social studies" (p. 3). The debate over what to teach students during social studies class has lingered since the 1916 Report of the Social Studies Committee of the National Education Association (NEA) Commission on the Reorganization of Secondary Education, and "the debate over the nature, purpose, and content of social studies curriculum continues today" (Ross, 2006, p. 2). Until recently, social studies professionals suggested that social studies was perceived as inferior to other subjects because it lacked clear, well-defined curriculum. Today, however, the debate has been stifled in states that have adopted specific grade-level content standards for social studies, and perhaps more importantly, standardized assessments linked to those content standards.

The purpose of this study was to compare the Michigan Elementary Social Studies Grade-level Content Expectations (GLCEs) against elementary teacher candidates' perspectives on the social studies curriculum, elementary social studies textbooks, and elementary social studies teacher education methods textbooks. Though there are clear national and state standards for social studies, which incidentally are often not consistent with each other, teacher candidates receive mixed messages about social studies content. For example, teacher education programs strive to provide candidates with field-based experiences to observe and practice teaching; however, elementary textbooks often do not correlate with state standards, and it is widely agreed that textbooks dominate elementary social studies teaching (U.S. Department of Education, 2001; Evans, 2010). Similarly, elementary social studies methods texts vary widely in their coverage of the various components of social studies.

\section{Theoretical Framework}

An examination of the social studies curriculum must consider two separate components: curriculum and social studies (Ross, 2006). Numerous definitions of curriculum exist and vary between narrow, subject-centered perspectives and broader definitions centering on comprehensive experiences (Wiles \& Bondi, 2011). Accelerated by the passing of NCLB, the dominant definitions of curriculum over the past decade have centered on intended learning outcomes, or the results of instruction (Parkay, Hass, \& Anctil, 2010). With nearly all states 
having adopted the Common Core State Standards (www.corestandards.org/) in mathematics and English-language arts, and similar standards for social studies on the horizon, debates over the definition of curriculum have been amplified (Gewertz, 2011). Some suggest that curriculum should designate broad frameworks, while others advocate scripted, day-to-day plans for teachers. Most indications suggest that future mandates will include more specificity rather than less.

Though it can be argued that the intent and content of social studies cannot be separated, at issue is the central question: What is "social studies?" Countless articles and books have discussed how the social studies curriculum has evolved from the first public schools of the $17^{\text {th }}$ century up to the present. The political, economic, and religious influences on the social studies curriculum cannot be overstated (Beck, McKeown, \& Gromoll, 1989; Evans, 2004; Fallace, 2008; Ross, 2006). Unlike mathematics and science, which face their own curricular disputes, social studies is contentious by its very nature because it is a study of people and is in large part subjective. Since the study of people includes a nearly infinite amount of material, decisions must be made regarding what should be included, and consequently, what should be excluded.

The earliest U.S. schools offered courses specifically in history, and it wasn't until the 1916 report from the National Education Association that social studies became generally recognized (Evans, 2004; Ross, 2006). Several reports on social studies followed and lead to countless debates over the content and purpose of social studies. Common ideologies include whether we should use a "disciplinary approach," a "social issues approach," or a "social justice approach” (Ross, 2006, p. 2). World and national events have always played a large role in shaping the social studies curriculum. For example, the world wars lead to increased emphasis on geography and war history, and the Cold War era lead to increased attention to nationalism, democracy, and capitalism (Evans, 2004). Following Sputnik in 1957 and again following the passage of NCLB in 2002, social studies was deemphasized as other subjects became more prominent.

The standards movement, initiated by the Charlottesville Education Summit of 1989, which was attended by all 50 governors, and accelerated by Clinton's 1994 Goals 2000: Educate America Act, lead to national standards adopted by the National Council for the Social Studies (NCSS) in 1994. Despite a national controversy over the National History Standards and lingering debate over whether social studies should remain a broad field or one dominated by history and geography, the NCSS published its Ten Thematic Strands in Social Studies, which remain in place today. Although the teaching of history had dominated social studies education since the inception of public schools, the NCSS Ten Thematic Strands (www.socialstudies.org/standards) define social studies as a broad, integrated course of study. Similarly, the Michigan Curriculum Framework, adopted by the Michigan Department of Education in 1995, identified K-12 standards and benchmarks for history, geography, civics, economics, public discourse, and citizen involvement. More recently in 2007, the Michigan Department of Education further refined the standards and benchmarks, which were grouped by early elementary, later elementary, and middle school, into specific grade-level content expectations (GLCEs). In essence, the GLCEs mandated to Michigan teachers specifically 
what they must teach students.

\section{Purpose}

This paper stems from a first-day-of-class activity I've done with my elementary teacher candidates for several semesters. Simply, I've asked them, "What is social studies?” After noticing that their responses tended to be limited, ambiguous, and not consistent Michigan's social studies standards, I decided to study the phenomena formally. I sought to compare teacher candidates' perceptions of social studies with what most of them would be mandated to teach during student teaching and in their own classrooms, the GLCEs. In addition, I wanted to know if the social studies textbooks they were using during their field placements were consistent with the GLCEs. Finally, I wanted to analyze elementary social studies methods texts to determine the extent to which their content is consistent with the GLCEs.

\section{Methods}

To answer my research questions, I used mixed methods, specifically a fully-mixed, concurrent, equal status design (Leech \& Onwuegbuzie, 2009). For each of the four data sources, I mixed qualitative and quantitative collection, analysis, and interpretation. Mixed methods research "address much more comprehensive research purposes than do quantitative or qualitative research alone” (Onwuegbuzie \& Leech, 2004, p. 770). This study required me to be flexible in my investigation of the complex question I was seeking to answer. Combining methods allowed me to examine both what and how questions. Unbound by traditional research paradigms, I was able to triangulate my research through my data sources and analyses. 
Table 1. Michigan Grade Level Content Expectations

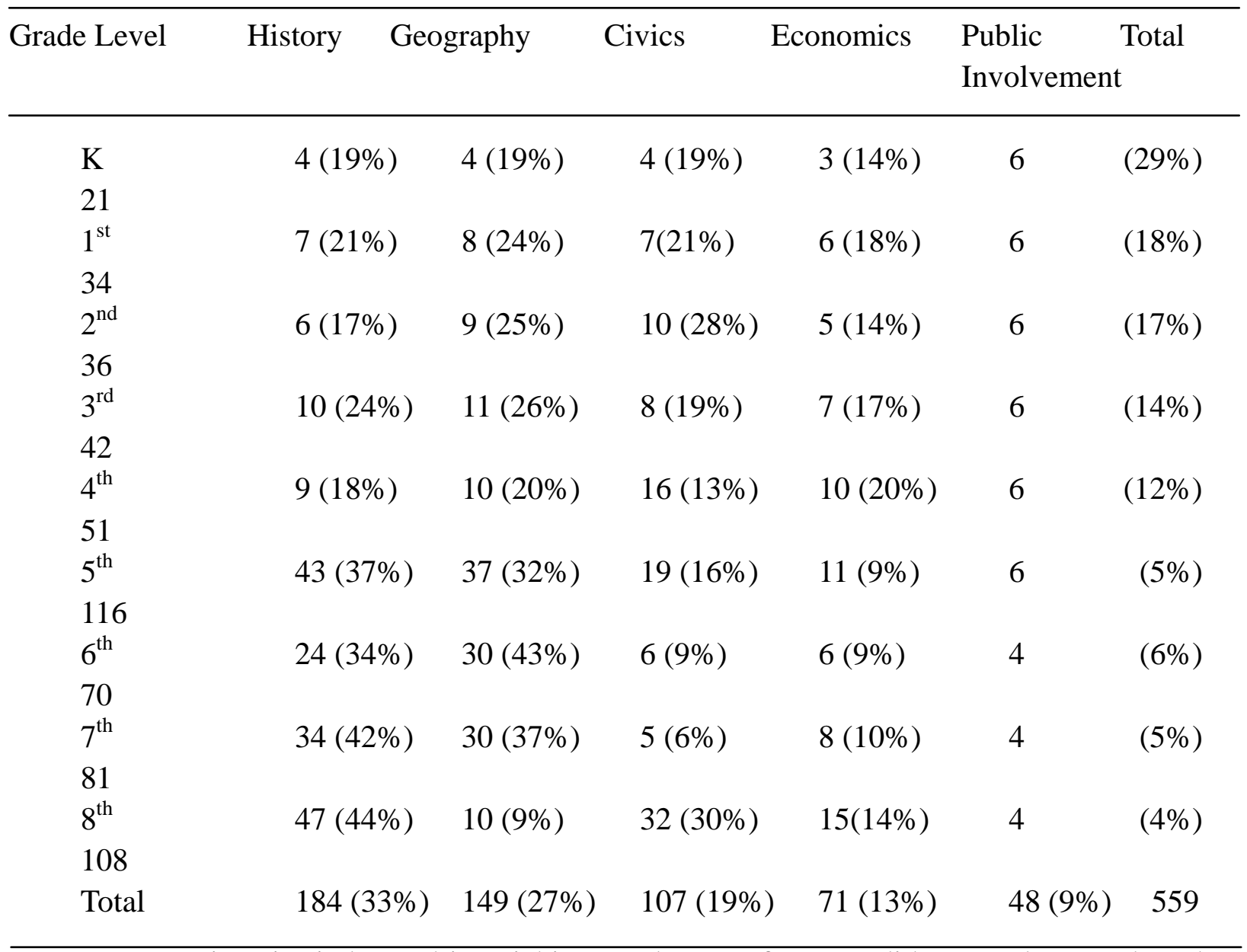

Because our university is located in Michigan and most of our candidates student teach and pursue teaching positions within the state, we rely heavily on the GLCEs in all of our methods courses. In addition, because Michigan's standardized test, the MEAP, assesses the GLCEs directly, all of the lessons our candidates are required to plan or deliver include objectives corresponding with the GLCEs. Thus, the first data source for this study includes a K-8 Social Studies GLCEs. Table 1 lists the percentage of GLCEs within each subcategory of social studies at each grade level.

The second data source includes the candidates' definitions of social studies. The participants include 44 elementary teacher candidates. The site of this study is a public university in Michigan where more than $90 \%$ of the students are White, and more than $75 \%$ of elementary teacher candidates are female. On the first day of their elementary social studies methods course, in their final semester before student teaching, I asked each student to answer the following question without looking in a textbook or online: "What is social studies?” I used classical content analysis, which is similar to constant comparison analysis except that the codes are predetermined and the researcher counts the number of times each code is utilized (Leech \& Onwuegbuzie, 2008). Though the GLCEs distinctly identify history, geography, civics, and economics as the four pillars of social studies, I added a fifth code, current events, after noting the frequency with which that theme appeared in the candidates' responses. See Table 2. 
Table 2. Elementary Teacher Candidates' Definitions of Social Studies

\begin{tabular}{ll}
\hline Included in Definition & Students $(\mathrm{n}=109)$ \\
\hline History & $90(83 \%)$ \\
Geography & $76(69 \%)$ \\
Civics & $46(42 \%)$ \\
Current Events & $44(40 \%)$ \\
Economics & $25(23 \%)$ \\
None & $3(3 \%)$ \\
\hline
\end{tabular}

For the third phase of this project, students working in pairs analyzed the social studies content of the textbooks used the classrooms where they were placed for their field placements. See Appendix C. Their task was simply to determine together what percentage of the lessons in texts fell into each of the four pillars of social studies in Michigan: history, geography, civics, and economics. To prepare students for this process, we examined several texts as a class in order to increase inter-rater reliability.

Finally, I examined the content of elementary social studies methods texts for the number of pages designated to the teaching of each of the four pillars specifically. The texts included only those that I had in my office, some of which I have used before, others of which were sent to me as examination copies. The list is by no means exhaustive. See Appendix D.

\section{Results}

The distribution of GLCEs across the four pillars of social studies plus Public Involvement is essentially even with a few exceptions. A paired samples test revealed a few statistically significant differences between the following: History and Economics $(t=2.59, p=.03)$; History and Public Involvement $(t=2.57, p=.03)$; and Geography and Public Involvement $(t$ $=2.60, p=.03$ ). Whereas the GLCEs for history, geography, civics, and economics, tend to center on specific content, the GLCEs for Public Involvement identify skills or processes such as "Express a position on a public policy issue in the school community and justify the position with a reasoned argument." Therefore, the only significant difference in areas of content between the pillars of social studies involves History and Economics. In other words, even though the Michigan Department of Education purports equal emphasis across the four subareas of social studies (http://www.michigan.gov/documents/mde/SSGLCE_218368_7.pdf), statistically significant priority is given to the teaching of history compared to economics, particularly at the upper elementary level.

When 109 elementary teacher candidates were asked to define social studies, their responses reveal dominance toward the two branches of social studies most common historically: History and Geography (see Table 2). Many noted history and geography explicitly in their definitions of social studies, while others included comments such as, "the study of our past," and "the study of physical and cultural aspects of where people live." Civics was mentioned approximately half as often as history. Nearly all of the responses I categorized under Civics 
included the word "government." Only 23\% of the students included something related to economics in their definitions. In addition to including those that mentioned economics specifically, I counted as economics students who wrote responses such as, "production and distribution of resources." Unexpectedly, Current Events was mentioned by $40 \%$ of the teacher candidates. Once again, most candidates mentioned the topic explicitly in their definitions; whereas, a few students mentioned Current Events indirectly such as, "Social studies also includes contemporary social problems that are present in society," and "Social studies looks at present times in order to gain a glimpse of what may be." Three students failed to mention any of the five categories of social studies directly. For example, one student wrote: "Social studies is the study of people," though one could argue that her simple definition implies all four pillars of social studies.

The candidates' evaluation of elementary social studies texts suggests that the content found in those texts is also not evenly distributed. A paired samples test revealed statistically significant differences between the number of lessons emphasizing the following: History and Geography $(t=3.20, p=.004)$; History and Civics $(t=4.82, p=.000)$; History and Economics ( $t=6.70, p=.000)$; and, Geography and Economics $(t=285, p=.009)$. The candidates' analyses suggest that elementary social studies test have a disproportionally high number of lessons emphasizing history and a disproportionally low number of lessons emphasizing economics. See Table 1.

Consistent with each of the other sources of data, the social studies methods texts also contained a significant difference in the number of pages dedicated to instruction on how to teach history and economics. See Table 3. A paired samples test revealed statistically significant differences between the number of pages devoted to instruction on the teaching of history compared to the number of pages devoted to instruction on the teaching of economics $(t=2.31, p=.046)$. Though the sample size is small, the theme persists. 
Table 3. Elementary Social Studies Methods Textbook Pages Devoted to How to Teach Specific Content

\begin{tabular}{|c|c|c|c|c|c|}
\hline Author & istory & Geography & Civics & Economics & Total Pages \\
\hline Armstrong (2007) & 12 & 11 & 15 & 7 & 329 \\
\hline Duplas (2011) & 11.5 & 9.5 & 9.5 & 13 & 441 \\
\hline Ellis (2010) & 26 & 40 & 22 & 2 & 405 \\
\hline Farris (2004) & 38 & 41 & 27 & 39 & 575 \\
\hline Maxim (2010) & 50 & 54 & 64 & 0 & 466 \\
\hline \multicolumn{6}{|l|}{ Savage } \\
\hline \& Armstrong (2007) & 12 & 11 & 15 & 7 & 329 \\
\hline \multicolumn{6}{|l|}{ Schell } \\
\hline \& Fisher (2007) & 2 & 2 & 2 & 4 & 276 \\
\hline Stockard (2001) & 24 & 16 & 3 & 2 & 484 \\
\hline \multicolumn{6}{|l|}{ Sunal } \\
\hline \& Haas (2011) & 39 & 38 & 38 & 32 & 503 \\
\hline Zarillo (2004) & 18 & 16 & 27 & 8 & 396 \\
\hline
\end{tabular}

\section{Limitations}

There are a number of limitations of this study. For example, it isn't clear if the percentage of elementary textbook lessons devoted to each of the four pillars of social studies is reliable since the analyses were conducted by teacher candidates. The analysis of their definitions on the first day of class revealed that they viewed social studies as predominantly history and geography. Therefore, it is possible that they were unable to recognize lessons in the textbooks as predominately civics or economics. Furthermore, we don't know the extent to which elementary teachers rely on or supplement their textbooks in their teaching.

\section{Discussion}

Until the national Common Core Standards initiative includes standards for social studies, state-mandated standards will prevail. Furthermore, as state social studies standards become more specific and explicit, and as further weight is given to standardized test scores, teachers will be held more accountable for matching their teaching to those specific content expectations. It is widely agreed that "what gets tested gets taught."

The results of this study suggest that the teaching of history dominates the content of social 
studies. Nevertheless, advocates for the teaching of history still lament attention given to the other sub-categories under the broad category of social studies. In a 2009 report funded by the Lexington Institute, Holland wrote, "A basic problem is that history is often tucked under the umbrella of social studies - a mishmash of everything from global studies to sociology, in which critical figures and lessons from American history are overlooked" (p. 2). The recent Fordham report (Stern \& Stern, 2011) gave D’s and F's to 29 states for their U.S. history standards and lamented "that history content remains obscured by the social studies fog" (p. 9). Clearly, those who support a traditional curricular perspective toward the teaching of history resent the emphasis spread more broadly across the other sub-categories of social studies. Yet even within the history sub-discipline of social studies there are divisions. World history receives much less advocacy than United States history. During the George W. Bush administration, more than $\$ 700$ million in federal funds were granted to materials and training for the teaching of U.S. history, but no federal money was designated for teacher development in world history (Martin et al., 2008).

Ever since the 1988 Bradley Commission report that recommended all social studies teaching in kindergarten through sixth grade center on history, advocates of the other sub-categories within the social studies umbrella have been fighting for their slice of the social studies pie. Unlike mathematics and English language arts, social studies remains fractured with subspecialists who lobby for their cause. For example, a 2008 report from the National Council on Economic Education stated, "[M]uch more work still needs to take place in terms of placing a greater emphasis on economics and personal finance in the K-12 curriculum” (p. 3). Similarly, proponents of civic education campaign for emphasis on their subject. In a study paid for by the American Enterprise Institute, Farkas and Duffett (2010) wrote: "[P]ublic school teachers believed that social studies is losing ground to other subject areas and that civics in particular is begin neglected.” (p. 1). Likewise, in a report commissioned by the American Bar Association and the Campaign for the Civic Mission of Schools, Torney-Purta and Wilkenfeld (2009) suggested that interactive civic education is vital to scoring high on $21^{\text {st }}$ Century Competencies. In much the same manner, geography education has its advocates. A 2008 report from the National Geographic Society suggested: "From a society-wide perspective, geography is probably the most important subject we can teach our young people to prepare them for the major challenges facing societies around the world" (Edelson, p. 2). Similar to advocates of other sub-categories of social studies, Edelson expressed disdain over the lack of respect geography has received, stating: "I have learned that geography is as misunderstood as it is disrespected" (p. 1) and, "[G]eography is the forgotten stepchild of education reform” (p. 4.)

Few people would argue that any of the four pillars of social studies aren't important. However, the problem at hand centers on the opportunity cost of spending limited time on one topic versus another. With the exception of some charter schools, the time allocated for instruction in US schools has not changed in over 100 years. Because instructional time is fixed, or in the case of social studies teaching, shrinking, the opportunity cost of emphasizing one area of social studies over another is contentious and perhaps, irrevocable.

The State of Michigan, borrowing from the NCSS standards, has established clearly defined 
content expectations for each grade level. These expectations include nearly equal attention to history, geography, civics, and economics in the early grades with more attention on history at the upper elementary level. The results of this study suggest, however, that history and geography dominate teacher candidates' exposure to social studies education. Conversely, economics is not given equal credence in any of the four data sources used in this study. For example, one $6^{\text {th }}$ grade textbook used in one of our candidates' field placements contains only $2 \%$ of the lessons devoted to economics even though $9 \%$ of the $6^{\text {th }}$ grade GLCEs are designated to economics content. This suggests that a $6^{\text {th }}$ grade teacher using that textbook would need to supplement the text with outside resources. On the other hand, one $8^{\text {th }}$ grade textbook contained $80 \%$ of its lesson devoted to history, whereas only $44 \%$ of the GLCEs included history objectives. This suggests that an $8^{\text {th }}$ grade teacher using that text would be wise to skip some of the history lessons in the text in order to devote more time to other content.

The number of objectives an elementary social studies teacher must teach each year is staggering - on average, 62 social studies GLCEs per year. Teachers are expected to teach each GLCE and not to spend time on topics not included in the GLCEs. And now, more than ever before, the consequences of autonomous social studies teaching are real. Leahey (2010, p. 41) posited:

The entire system of standardized education relies on a culture of compliance where local school officials and teachers are compelled to carry out an educational system where the curricular content, pedagogical strategies, and methods of evaluation are determined by external authorities. Textbooks serve as the primary reference point for delivering the state curriculum. Accountability measures and standardized exams ensure that teachers who deviate from the prescribed ritual will be easily identified, corrected, and in some cases sanctioned.

With teacher pay now linked directly to student test scores as result of state's quest to receive Race to the Top grants, it is hard to argue with Leahey. Teachers have a vested interest in teaching the content specifically upon which their students will be evaluated and upon which their pay will depend.

It is important that elementary teacher candidates, and subsequently classroom teachers, recognize that social studies, as mandated by the Michigan Department of Education, consists of nearly equal parts history, geography, civics, and economics, and that elementary social studies texts often do not contain content consist with what they are expected to teach. Furthermore, elementary social studies teacher educators need to recognize that their students might come to class with a bias toward history and geography that is reinforced by some methods texts. It would be wise for elementary social studies teachers to supplement resources in civics and economics.

\section{References}

Bolick, C. M., Adams, R., \& Willox, L. (2010). The marginalization of elementary social studies in teacher education. Social Studies Research and Practice, 6(2), 1-22. 
Bradley Commission on History in Schools, Educational Excellence Network. (1988). Building a history curriculum: Guidelines for teaching history in schools (ERIC Document Reproduction Service No. ED 310 008).

Center on Educational Policy (Dec 2007). Choices, changes, and challenges: Curriculum and instruction in the NCLB era. (ECS Document No. 7511). Retrieved from http://www.ecs.org/html/Document.asp?chouseid=7511

Duplas, J. A. (2011). Teaching elementary social studies. $3^{\text {rd }}$ Ed, Belmont, C.A: Wadsworth.

Edelson, D. C. (2008). Repositioning geography education. Retrieved from National Geographic Society website: http://www.nationalgeographic.com/foundation/pdf/Edelson_repositioning_Geo.pdf

Ellis K. A., (2010) Teaching and learning elementary social studies, $9^{\text {th }}$ Ed, Boston: Pearson.

Evans, R. W. (2004). The social studies wars. New York: Teachers College Press.

Evans, R. W. (2010, May). On the grammar of social studies. Paper presented at annual meeting of the American Education Research Association, Denver, CO.

Farkas, S., \& Duffett, A. M. (2010). High schools, civics, and citizenship. Retrieved from American Enterprise Institute website: http://www.aei.org/docLib/Citizenship-Foreword.pdf

Farris, J. P. (2004) Elementary \& middle school social studies: An interdisciplinary multicultural approach. $4^{\text {th }}$ Ed, New York: McGraw-Hill

Fitchett, P. G., \& Heafner, T. L. (2010). A national perspective on the effects of high-stakes testing and standardization on elementary social studies marginalization. Theory and Research in Social Education, 38(1), 114-130.

Gewertz, C. (2011, March). 'Curriculum' definition raises red flags. Education Week. Retrieved from http://www.edweek.org/ew/articles/2011/03/23/26curriculum.h30.html?tkn=WRYF8u\%2BC2 cweGQ6tFHos80uGFXuqPOEACVau\&cmp=clp-edweek

Heafner, T. L (2007). Advocating for social studies: Becoming AGENTS for change. Social Studies and the Young Learner, 20(1), 26.

Heafner, T. L., Lipscomb, G., \& Rock, T. (2006). To test or not to test?: The role of testing in elementary social studies. Social Studies Research and Practice, 1(2), 145-164. Retrieved March 4, 2007, from http://www.socstrp.org/issues/PDF/1.2.1.pdf

Holland, R. (2009). The teaching of American history: Promise and performance. Retrieved from Lexington Institute website: http://www.lexingtoninstitute.org/library/resources/documents/Education/TeachingofAmerica nHistory.pdf

Leahey, C. R. (2010). Whitewashing war: Historical myth, corporate textbooks, and possibilities for democratic education. New York: Teachers College Press. 
Leech, N. L., \& Onwuegbuzie, A. J. (2008). Qualitative data analysis: A compendium of techniques and a framework for selection for school psychology research and beyond. School Psychology Quarterly, 23, 587-604. http://dx.doi.org/10.1037/1045-3830.23.4.587

Leech, N. L., \& Onwuegbuzie, A. J. (2009). A typology of mixed methods research. Quality \& Quantity, 43, 265-275. http://dx.doi.org/10.1007/s11135-007-9105-3

Leming, J. S., Ellington, L., \& Schug, M. (2007). The state of social studies: A national random survey of elementary and middle school social studies teachers. Social Education, 70(5) 5 (September 2007): 322-327.

Lintner, T. (2006). Social Studies (still) on the back burner: Perceptions and practices of K-5 social studies instruction. Journal of Social Studies Research, 30(1), 3-8.

Martin, D., Schneider, J., Fogo, B., \& Kon, J. (2008). A report on the state of U.S. history education. Retrieved from National History Education Clearinghouse website: http://teachinghistory.org/system/files/NHEC_Report.pdf

Maxim, W. G. (2010) Dynamic social studies for constructivist classrooms. $9^{\text {th }}$ Ed, Boston: Pearson.

McGuire, M. (2007). What happened to social studies? The disappearing curriculum. Phi Delta Kappan, 88(8), 620-624.

Michigan Curriculum Framework

(1995).

http://www.michigan.gov/documents/Social_Studies_Standards_122915_7.pdf

National Council on Economic Education. (2008). Economic, personal finance, and entrepreneurship education in our nation's schools in 2007. Retrieved from Council for Economic Education website: http://www.councilforeconed.org/about/survey2007/NCEESurvey2007.pdf

Onwuegbuzie, A. J., \& Leech, N. L. (2004). Enhancing the interpretation of "significant" findings: "The role of mixed methods research. The Qualitative Report, 9(4), 770-792.

Parkay, F. W., Hass, G., \& Anctil, E. J. (2010). Curriculum leadership. Boston: Allyn \& Bacon.

Ross, E. W. (2006). Social studies teachers and curriculum. In E. Ross (Ed), The social studies curriculum (pp. 1-14). Albany: State University of New York Press.

Savage, T. V. \& Armstrong, D. G. (2007). Effective Teaching in Elementary Social Studies. $6^{\text {th }}$ Ed, Upper Saddle River N.J: Pearson.

Schell, E., \& Fisher, D. (2007) Teaching social studies: A literacy-based approach. Upper Saddle River, N.J: Pearson.

Stecher, B.M., \& Chun, T. (2001). School and classroom practices during two years of education reform in Washington State (CSE Technical Report 550), Los Angeles, CA:

University of California National Center for Research on Evaluation, Standards, and Student 


\section{Macrothink}

Testing, 14.

Stern, S. M., \& Stern, J. A. (2011). The state of state U.S. history standards 2011. Retrieved from the Thomas Fordham Institute website: http://www.edexcellence.net/publications-issues/

Stockard, W. J., Jr. (2001) Methods and resources for elementary and middle-school social studies. Chicago: Waveland

Sunal, S. C., \& Haas E. M. (2011) Social Studies for the elementary and middle grades a constructive approach. $4^{\text {th }}$ Ed, Boston: Pearson.

Torney-Purta, J., \& Wilkenfeld, B. S. (2009). Paths to 21st century competencies through civic education classrooms. Silver Spring, MD: American Bar Association.

U.S. Department of Education, Office of Research and Improvement, National Center of Education Statistics (2001). The Nation's report card: U.S. History 2001. (NCES 2002-483). Washington, DC: Author.

VanFossen, P. J. (2005). "Reading and math take so much of the time...": An overview of social studies instruction in elementary classrooms in Indiana. Theory and Research in Social Education, 33(3), 376-403.

Wiles, J. W., \& Bondi, J. C. (2011). Curriculum development: A guide to practice. Upper Saddle River, NJ: Pearson.

Zarrillo, J. J. (2004) Teaching elementary social studies: Principles and applications. $2^{\text {nd }}$ Ed, Upper Saddle River, N.J: Pearson.

Zevin, J. (2007). Social studies for the twenty-first century. Mahwah, NJ: Lawrence Erlbaum Associates. 


\section{Appendix 1}

Percentage of Elementary Social Studies Textbook Lessons Devoted to Specific Content

Text Title, Grade, \& Publisher
People and Places ( $1^{\text {st }}$ grade)
Macmillan/McGraw-Hill

(2005)

About My Community ( $2^{\text {nd }}$ Grade)

Harcourt

14

History

Geography

Civics

Economics

(2003)

We Live Together ( $2^{\text {nd }}$ grade)

Macmillan/McGraw-Hill

22

21

25

(2005)

Our Communities ( $3^{\text {rd }}$ Grade)

Macmillan/McGraw-Hill

26

16

21

(2005)

Communities ( $3^{\text {rd }}$ Grade)

Scott Foresman

39

19

19

23

(2003)

Michigan Social Studies ( $4^{\text {th }}$ Grade)

Scott Foresman

51

19

15

15

(2004)

Our Country's Regions (4 ${ }^{\text {th }}$ Grade)

Macmillan/McGraw-Hill

40

24

14

22

(2005)

Our Michigan Adventure ( $4^{\text {th }}$ Grade)

Hillsdale

(1998)

Build our Nation ( $5^{\text {th }}$ Grade)

Houghton-Mifflin

43

32

13

12

(1997)

Our Community ( $5^{\text {th }}$ Grade)

Silver Burdett Ginn

45

23

17

15

(1993)

Our Nation (5 ${ }^{\text {th }}$ Grade)

Macmillan/McGraw-Hill

45

20

20

15

(2005) 
We the People - Build our Nation ( $5^{\text {th }}$ Grade)

Houghton-Mifflin

(2003)

The American Journey Early Years $\left(5^{\text {th }}\right.$ Grade)

Glencoe/McGraw-Hill

51

10

14

25

(2009)

Western World (6 $6^{\text {th }}$ Grade)

Holt, Reinhart, \& Winston

27

66

5

2

(2009)

World Cultures and Geography: Western Hemisphere ( $6^{\text {th }}$ Grade)

McDougel Littell

36

34

16

14

(2008)

World Studies: Latin America $\left(6^{\text {th }}\right.$ Grade)

Pearson Prentice Hall 28

33

19

20

(2008)

World Studies: The United States and Canada $\left(6^{\text {th }}\right.$ Grade)

Pearson Prentice Hall

27

33

30

10

(2008)

Eastern Hemisphere ( $7^{\text {th }}$ Grade)

Holt, Reinhart and Winston

60

26

6

8

(2007)

Journey Across Time: The Early Ages ( $7^{\text {th }}$ Grade)

$\begin{array}{lllll}\text { McGraw-Glencoe } & 50 & 20 & 20 & 10\end{array}$

(2008)

World Cultures and Geography: Eastern Hemisphere $\left(7^{\text {th }}\right.$ Grade)

McDougal Littell

31

34

19

16

(2008)

American History ( $8^{\text {th }}$ Grade)

McDougal Littell

80

5

10

5

(2008)

United States History ( $8^{\text {th }}$ Grade)

Holt, Rinehart and Winston

47

18

21

14 (2009) 